\title{
THE IMPACT OF BOARD CAPITAL ON INTERNATIONALIZATION OF SMES: INITIAL THEORETICAL CONSIDERATIONS
}

\author{
Monika BUZAVAITE ${ }^{1}$, Renata KORSAKIENE ${ }^{2}$ \\ 1,2Vilnius Gediminas Technical University, Faculty of Business Management, Vilnius, \\ Lithuania
}

Corresponding authore-mail: monika.buzavaite@vgtu.lt

\begin{abstract}
The study aims to investigate the relationship between Board capital and internationalization of SMEs. The study implements a systematic review and synthesis of scientific literature. The article presents useful insights into the concept of Board capital, Agency, Resource dependency, Institutional theories, and Resource-Based view. These theories give us a better understanding of Board capital, the firm's management and behavior. The analysis of recent studies suggests that external members of the Board might positively affect internationalization outcomes and be useful in overcoming obstacles during the initiation of international activities. Nevertheless, international entrepreneurship literature is still lacking studies considering Board capital. A deeper investigation of Board capital factors impacting the internationalization of SMEs can be stated as a future research direction.
\end{abstract}

Keywords: Board capital, External directors, Internationalization, SMEs.

JEL Classification: M10, M13, M16, M19

\section{INTRODUCTION}

The studies demonstrate the significant relationship between management and the firm's performance (Wright \& Mcmahan, 2011). On the other hand, the discussion on effective board surrounds the behaviors of boards and interrelate these behaviors with the firm's performance. However, the researches on the link between boards and the outcome of the firm such as internationalization is scant (Barroso et al., 2011) and thus, requires deeper investigations.

This research aims at contributing to academic and managerial knowledge by researching the relationship between human capital and the results of SMEs internationalization to obtain better theoretical understanding and to formulate suggestions for future investigations. The research methods include systematic review and synthesis of SMEs' internationalization studies, which considers Board capital as an impactful factor for internationalization process success in SMEs. The following chapter presents the board capital concept and related theories, such as Agency theory and Resource dependency theory. The second part of the article is dedicated to the interrelationships between board capital and internationalization. 


\section{THEORETICAL BACKGROUND ON BOARD CAPITAL}

The literature defines board capital as consisting of human capital and relational capital, where human capital refers to directors' expertise, experience, knowledge, reputation, skills and relational capital as network relationships with other firms or other valuable connections (Johnson et al., 2013). In other words, board capital is a combination of the human and social capital of the directors (Haynes \& Hillman, 2010). Though extensively investigated in corporate governance studies, the resent researches on boards' role in small firms have attracted considerable attention of scholars (Arzubiaga et al., 2018). Moreover, some scholars extended the definition of top management teams of SMEs by including the members of boards (Nielsen, 2010). The explanation resides in the fact that external directors may provide external support and necessary resources to the firm. Thus, the boards of directors may help the firms to overcome the issues of newness and smallness.

Stemming from the wider governance literature, the studies of the board adopt various theoretical perspectives. The main function of the board in the company usually includes monitoring or controlling and providing resources, and it correlates to the firm's performance. Grounded in the agency theory, the monitoring function of the board is described as the responsibility of directors to monitor managers on behalf of shareholders. While agency theory explains the delegation of functions' which occurs between principals and agents, the delegation in the firms is observed between owners and managers or managers and workers. The goals of owners and managers usually vary and thus, owners have to monitor managers' activities to ensure goals reachability (Van Puyvelde et al., 2012). In spite of the aim to re-align different goals, the theory tackles the issues of risk-sharing, efficiency, information sharing and agent's performance evaluation (Zu \& Kaynak, 2012). One of the main streams of the literature focus on governance and control functions in the organization. It includes the monitoring function of the board of directors, monitoring strategies, bonding techniques and capitalization forms (Shapiro, 2005).

The provision of resources refers to the managers' ability to bring resources to the firm. The studies suggest that the service role of the boards includes legitimization, external linkage and resource provision, information gathering, advice and counseling (Ingley et al., 2016). The theoretical background of this function lies in the Resource dependency theory (RDT), which could be supplemented by institutional theory (Dependence \& Dalziel, 2016). RDT explains these needs of the organization to seek resources from the other sources in the environment (Hessels \& Terjesen, 2010). Furthermore, RDT refers to the social capital of the board, which is useful for quick access to crucial resources. Due to the networks with other directors and executives, directors can take advantage of facilitated communication, important information, and strategic knowledge. It also serves in opportunity recognition and business development cases to make strategic decisions (Chen, 2013).

Though RDT is less often used in explaining boards' behavior than agency theory, RDT suggests mechanisms of the links to critical resources from the environment through the boards. The studies mostly focused on the board size and composition as factors influencing boards' possibilities to obtain resources. The investigations suggested that the board of directors is beneficial for the company as advisers, networkers and resource obtainers. These benefits are closely related to the board capital (Hillman et al., 2009). Other scholars focus on the positive impact of board capital on all functions of the board, such as service, monitoring, and the provision of resources. Motivation and ability formed by relevant experience, knowledge, and skills are necessary for directors in order to make the best decisions. One stream of studies in this field investigates the impact of boards' capital 
elements on the ability to perform advisory and governance functions. Such an approach is derived from a Resource-based view, which explains how the elements of board capital are used in the firm and bring a certain value to the firm by developing a competitive advantage (Barroso et al., 2011). While Resource-based view considers unique resources, leading to competitive advantage, RDT focuses on resource scarcity, which makes multipleorganizations compete for the same resources. Institutional and agency theories supplement previously mentioned theories and explain firms' management and behavior.

\section{BOARD CAPITAL AND INTERNATIONALIZATION OF SMES}

Stemming from the resource dependence theory, the role of the board in SMEs is associated with the provision of necessary resources to the firm. The studies suggest that the board serves as the "boundary spanner" and reduces the dependence on external resources (Bjørnåli \& Aspelund, 2012). Moreover, the social networks available to the board appear to be another significant resource. Some scholars conclude that external members of the board provide reputation and connections with external firms and individuals (Calabro et al., 2017). Thus, the recognition that the board might contribute to the professionalization of the firm through counseling, information, and social interactions has been increasing. These insights have led to the idea that the board of directors could support the management team in the decision-making process and the execution of strategy.

The internationalization of small firms appears to be a significant strategy leading to the growth of the firm. However, small firms face a number of obstacles and thus, are not reluctant to expand internationally. The firms are constrained by limited financial and managerial resources and lack the necessary knowledge in international markets. Thus, the involvement of external directors could significantly contribute to overcoming these issues. The external members of the board rely on the networks and competencies developed from previous experiences (Calabro et al., 2017). These members of management are necessary aiming to create a variety of views which are necessary for dealing with a complex issue such as internationalization. For instance, the scholars suggest that external board members with diverse industrial experience have more protentional relationships and subsequently speed up international sales (Bjørnåli \& Aspelund, 2012). Furthermore, the connections with some industry players might help to bring necessary for internationalization resources to the firm. Apparently, external members of the board contribute to internationalization due to complementary human capital and external relationships. These insights have encouraged scholars to seek explanations and investigate why and how the board of directors contributes to the internationalization of the firms.

The investigation of Norwegian SMEs disclosed that the presence of external directors positively influenced export intensity (Calabro \& Mussolino, 2013). These results have led to the conclusion that small firms benefit from outside directors due to their value to undertake and sustain internationalization. Moreover, the scholars suggest the possibility to combine formal (independence in board behavior) and informal (relational norms and trust) governance mechanisms. Furthermore, the investigations suggest that the board's involvement in the advisory tasks is significantly associated with the export intensity (Calabro et al., 2009). The investigation of 248 Belgian SMEs disclosed that the boards' involvement positively affects the export scope, i.e. the geographic distribution of the firm's sales (Bauweraerts et al., 2019). The study on Norwegian spin-offs found that international sales are achieved due to board members with diverse functional background (Bjørnåli \& 
Aspelund, 2012). Apparently, a resource-based perspective let us explain the board's role in the internationalization process.

\section{CONCLUSION}

Deep systematic review and synthesis let us identify several theories, which compose the theoretical background of the Board capital topic. Agency theory explains the monitoring function of Board capital and task delegation. While Resource dependency theory redirects scientific focus to another important function of Board capital - resource provision. Such theory as a Resource-Based view indicates the elements of Board Capital as a source for competitive advantage. Overall, these theories give us a better understanding of Board Capital, the firm's management and behavior.

Implications of this study to management science occur through awareness of the Board capital role in the internationalization of SMEs. While Board capital studies are more associated with multinational companies, more attention to the small firms is needed from the scholars, investigating board capital. The Board of directors usually is beneficial for the firm due to control, service, and resource dependency tasks. Notably, the service task of the board has been getting wider attention in recent years. However, this topic still requires more effort to reveal service tasks' importance.

The internationalization of SMEs is one of the growth strategies that companies can apply. However, its success is related to other strategical decisions of the firm. A number of studies highlighted that hiring the external members of the board might be an effective strategy to overcome internationalization obstacles, which SMEs face due to smallness and newness. The studies indicated the possible impact of the externals directors on internationalization results, such as export intensity or scope. However, scholars still strive to determine the Board of directors' role in international activities.

Nevertheless, the literature on human capital and internationalization of SMEs appears to be vast, there is a lack of board capital studies, considering internationalization aspects. The conducted analysis lets us formulate future research directions, considering board capital factors for deeper investigation in terms of SMEs internationalization. The scholars should focus on the obstacles of internationalization that SMEs face and try to integrate the roles of Board capital, which might facilitate international expansion. Another research stream could be related to the broader vision of the Board capital role in the internationalization process in SMEs.

\section{REFERENCES}

Arzubiaga, U., Kotlar, J., De Massis, A., Maseda, A., \& Iturralde, T. (2018). Entrepreneurial orientation and innovation in family SMEs: Unveiling the (actual) impact of the Board of Directors. Journal of Business Venturing, 33(4), 455-469. https://doi.org/10.1016/j.jbusvent.2018.03.002

Barroso, C., Villegas, M. M., \& Pérez-Calero, L. (2011). Board influence on a firm's internationalization. Corporate Governance: An International Review, 19(4), 351-367. https://doi.org/10.1111/j.14678683.2011.00859.x

Bauweraerts, J., Sciascia, S., Naldi, L., \& Mazzola, P. (2019). Family CEO and board service: Turning the tide for export scope in family SMEs. International Business Review, 101583. https://doi.org/10.1016/j.ibusrev.2019.05.003

Bjørnåli, E. S., \& Aspelund, A. (2012). The role of the entrepreneurial team and the board of directors in the internationalization of academic spin-offs. Journal of International Entrepreneurship, 10(4), 350-377. https://doi.org/10.1007/s10843-012-0094-5 


\section{RTU 60TH INTERNATIONAL SCIENTIFIC CONFERENCE ON ECONOMICS AND ENTREPRENEURSHIP SCEE'2019 PROCEEDINGS}

Bruton, G. D., Ahlstrom, D., \& Li, H.-L. (2010). Institutional Theory and Entrepreneurship: Where Are We Now and Where Do We Need to Move in the Future?. Entrepreneurship Theory and Practice. Entrepreneurship Theory and Practice. http://doi.org/10.1111/j.1540-6520.2010.00390.x

Calabrò, A., Mussolino, D., \& Huse, M. (2009). The role of board of directors in the internationalisation process of small and medium sized family businesses. International Journal of Globalisation and Small Business, 3(4), 393-411. http://doi.org/10.1504/IJGSB.2009.032259

Calabrò, A., \& Mussolino, D. (2013). How do boards of directors contribute to family SME export intensity? The role of formal and informal governance mechanisms. Journal of Management \& Governance, 17(2), 363-403. https://doi.org/10.1007/s10997-011-9180-7

Chen, H. L. (2013). CEO tenure and R\&D investment: The moderating effect of board capital. The Journal of Applied Behavioral Science, 49(4), 437-459. https://doi.org/10.1177/0021886313485129

Chen, H.-L. (2014). Board Capital, CEO Power and R\&D Investment in Electronics Firms. Corporate Governance: An International Review, 22(5), 422-436. https://doi.org/10.1111/corg.12076

Dacin,T. M., Goodstein, J., \& Richard Scott, W. (2002). Institutional theory and institutional change: Introduction to the special research forum. Academy of management journal, 45(1), 45-56. https://doi.org/10.2307/3069284

Dependence, R., \& Dalziel, T. (2016). Boards of directors and firm performance : integrating agency and resource dependence perspectives, 28(3), 383-396. https://doi.org/10.2307/30040728

Haynes, K. T., \& Hillman, A. (2010). The effect of board capital and CEO power on strategic change. Strategic Management Journal, 31(11), 1145-1163. https://doi.org/10.1002/smj.859

Hessels, J., \& Terjesen, S. (2010). Resource dependency and institutional theory perspectives on direct and indirect export choices. Small Business Economics. Small Business Economics. http://doi.org/10.1007/s11187-0089156-4

Hillman, A. J., Withers, M. C., \& Collins, B. J. (2009). Resource dependence theory: A review. Journal of management, 35(6), 1404-1427. http://doi.org/10.1177/0149206309343469

Hofer, C., Eroglu, C., \& Hofer, A. R. (2012). The effect of lean production on financial performance: The mediating role of inventory leanness. International Journal of Production Economics, 138(2), $242-253$. https://doi.org/10.1016/j.ijpe.2012.03.025

Ingley, C., Khlif, W., \& Karoui, L. (2017). SME growth trajectories, transitions and board role portfolios: A critical review and integrative model. International Small Business Journal, 35(6), 729-750. https://doi.org/10.1177/0266242616680280

Johnson, S. G., Schnatterly, K., \& Hill, A. D. (2013). Board composition beyond independence: Social capital, human capital, and demographics. Journal of management, 39(1), 232-262. https://doi.org/10.1177/0149206312463938

Nguyen, T., Nguyen, A., Locke, S., \& Reddy, K. (2017). Does the human capital of board directors add value to firms? Evidence from an Asian market. Cogent Economics \& Finance. Cogent Economics \& Finance. http://doi.org/10.1080/23322039.2017.1385439

Nielsen, S. (2010). Top management team diversity: A review of theories and methodologies. International Journal of Management Reviews, 12(3), 301-316. https://doi.org/10.1111/j.1468-2370.2009.00263.x

Suddaby, R. (2010). Challenges for institutional theory. Journal of management inquiry, 19(1), 14-20. http://doi.org/10.1177/1056492609347564

Van Puyvelde, S., Caers, R., Du Bois, C., \& Jegers, M. (2012). The governance of nonprofit organizations: Integrating agency theory with stakeholder and stewardship theories. Nonprofit and voluntary sector quarterly, 41(3), 431-451. http://dx.doi.org/10.1177/0899764011409757

Wright, P. M., \& McMahan, G. C. (2011). Exploring human capital: putting 'human'back into strategic human resource management. Human resource management journal, 21(2), 93-104. https://doi.org/10.1111/j.1748$\underline{8583.2010 .00165 . \mathrm{x}}$

$\mathrm{Zu}, \mathrm{X} .$, \& Kaynak, H. (2012). An agency theory perspective on supply chain quality management. International Journal of Operations \& Production Management, 32(4), 423-446. https://doi.org/10.1108/01443571211223086 